Prepared in cooperation with the Washington Department of Fish and Wildlife

\title{
Evaluation of the Behavior and Movement of Adult Summer Steelhead in the Lower Cowlitz River, Washington. Following Collection and Release, 2013-2014
}

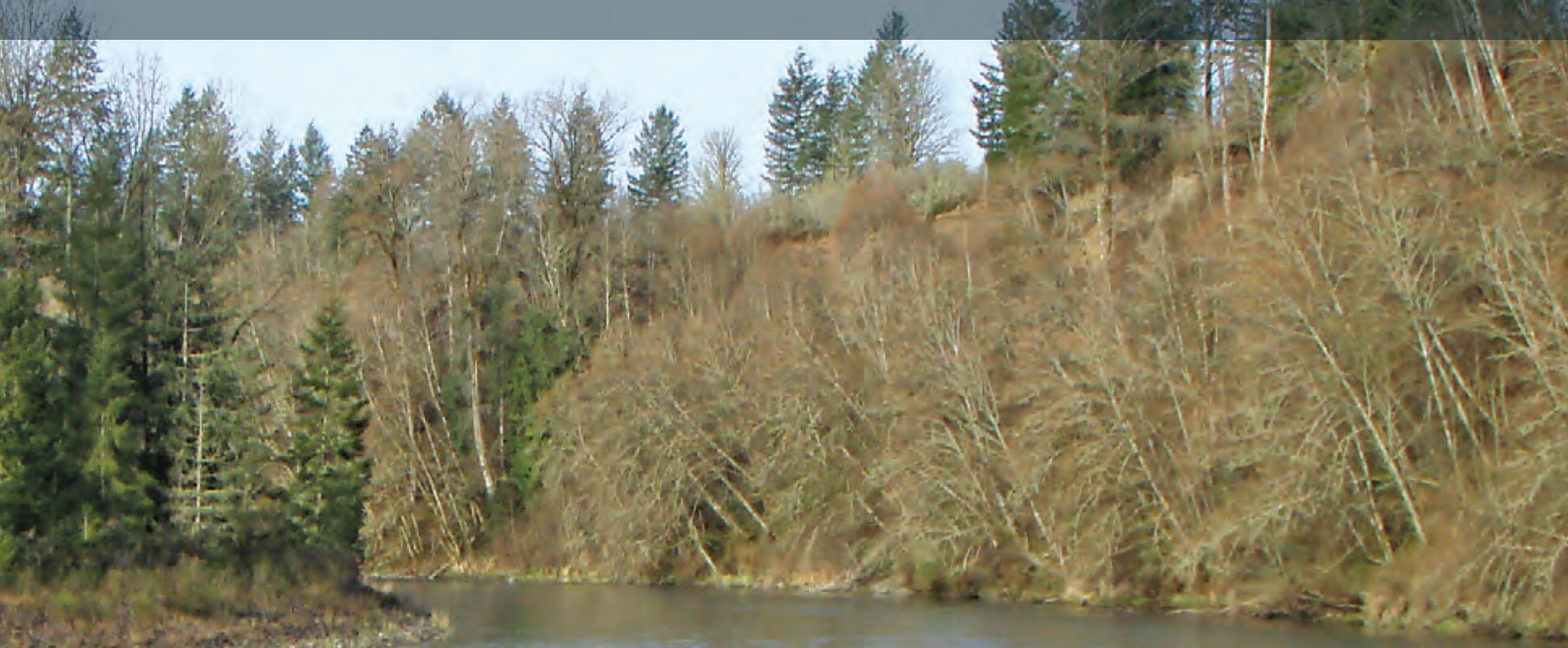

Open-File Report 2014-1122

U.S. Department of the Interior

U.S. Geological Survey

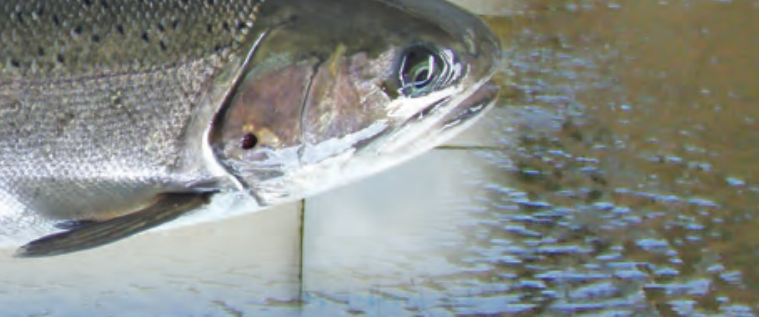


Cover: Photographs of the lower Cowlitz River and a summer steelhead that was collected at the Salmon Hatchery and recycled downstream. Photographs taken by Tobias Kock, U.S. Geological Survey. 


\title{
Evaluation of the Behavior and Movement of Adult Summer Steelhead in the Lower Cowlitz River, Washington, Following Collection and Release, 2013-2014
}

\author{
By Tobias J. Kock, Theresa L. Liedtke, Brian K. Ekstrom, Chris Gleizes, and Wolf Dammers
}

Prepared in cooperation with the Washington Department of Fish and Wildlife

Open-File Report 2014-1122

U.S. Department of the Interior

U.S. Geological Survey 


\section{U.S. Department of the Interior \\ SALLY JEWELL, Secretary}

\section{U.S. Geological Survey \\ Suzette M. Kimball, Acting Director}

U.S. Geological Survey, Reston, Virginia: 2014

For more information on the USGS-the Federal source for science about the Earth,

its natural and living resources, natural hazards, and the environment-visit

http://www.usgs.gov or call 1-888-ASK-USGS

For an overview of USGS information products, including maps, imagery, and publications, visit $h$ ttp://www.usgs.gov/pubprod

To order this and other USGS information products, visit $h$ ttp://store.usgs.gov

Suggested citation:

Kock, T.J., Liedtke, T.L., Ekstrom, B.K., Gleizes, Chris, and Dammers, Wolf, 2014, Evaluation of the behavior and movement of adult summer steelhead in the lower Cowlitz River, Washington, following collection and release, 20132014: U.S. Geological Survey Open-File Report 2014-1122, 20 p., http://dx.doi.org/10.3133/ofr20141122.

Any use of trade, firm, or product names is for descriptive purposes only and does not imply endorsement by the U.S. Government.

Although this information product, for the most part, is in the public domain, it also may contain copyrighted materials as noted in the text. Permission to reproduce copyrighted items must be secured from the copyright owner. 


\section{Contents}

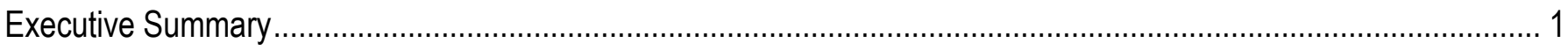

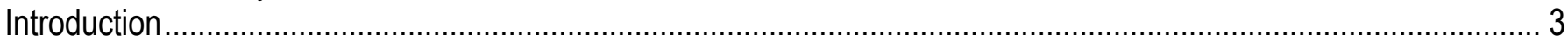

Methods

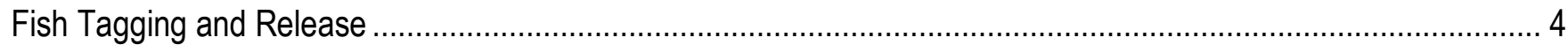

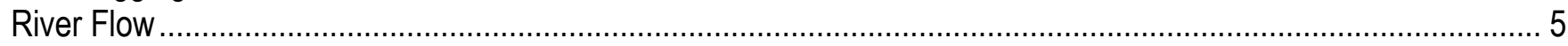

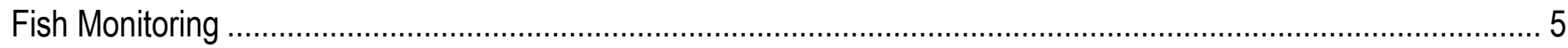

Results

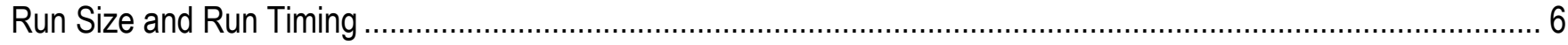

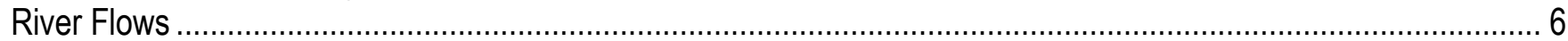

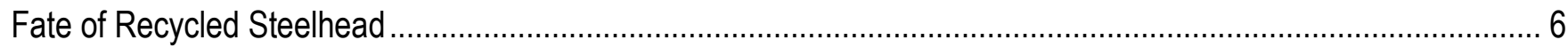

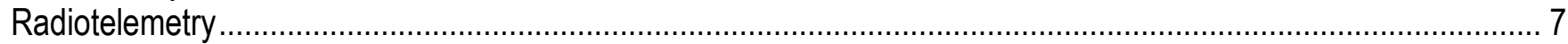

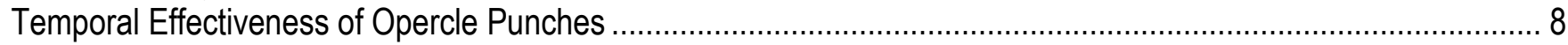

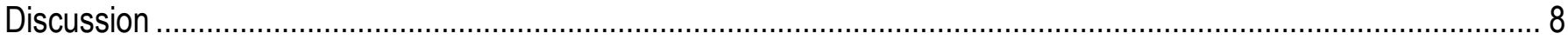

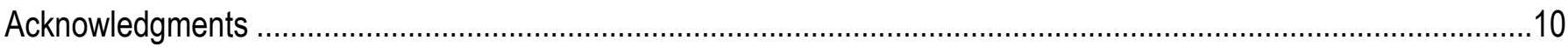

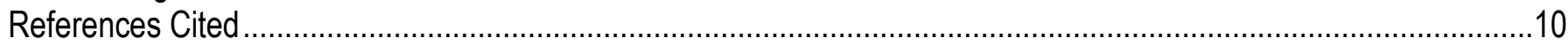

\section{Figures}

Figure 1. Schematic of lower Cowlitz River, Washington, showing where recycled steelhead were

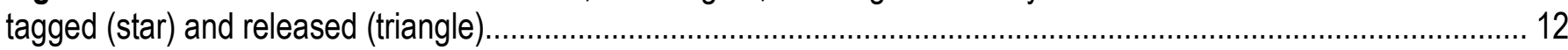

Figure 2. Photographs showing a Floy ${ }^{\circledR}$-tagged steelhead that was being opercle-punched (top); a fresh opercle punch and a radio transmitter antenna exiting the fish mouth (transmitter was located inside the fish and is not visible) (middle); and an opercle punch that had closed from tissue re-growth (bottom)

Figure 3. Graphs showing daily river flows (in cubic feet per second [ft3/s]; top) near Mayfield Dam

(U.S. Geological Survey streamgage No. 14238000) during June-December 2013, and the relation (ratio) between 2013 and average 2008-2012 flows (bottom), lower Cowlitz River, Washington.

Figure 4. Graph showing cumulative number of recycled steelhead that were captured by anglers or returned to Cowlitz Salmon Hatchery, lower Cowlitz River, Washington, 2013.

Figure 5. Graph showing percentage of weekly release groups of recycled steelhead that returned to the Cowlitz Salmon Hatchery, were captured by anglers, or were not known to have been removed from lower Cowlitz River, Washington, 2013-2014

Figure 6. Graph showing percentage of radio-tagged steelhead that made trips between the Cowlitz Trout and Salmon Hatcheries during study on the lower Cowlitz River, Washington, 2013.

Figure 7. Graph showing relation between the inside diameter of opercle punches (in millimeters [mm]) of adult steelhead and elapsed time (in days [d]) since tagging for a study on the lower Cowlitz River, Washington, 2012.... 18

\section{Tables}

Table 1. Tagging dates and numbers of adult hatchery steelhead that were marked for evaluation on the Cowlitz River, Washington, June 2013-February 2014.

Table 2. Summary of the fates of recycled steelhead that were released during a study on the Cowlitz River, Washington, 2013. 


\section{Conversion Factors}

Inch/Pound to SI

\begin{tabular}{|c|c|c|}
\hline Multiply & By & To obtain \\
\hline \multicolumn{3}{|c|}{ Length } \\
\hline mile (mi) & 1.609 & kilometer (km) \\
\hline \multicolumn{3}{|c|}{ Flow rate } \\
\hline cubic foot per second $\left(\mathrm{ft}^{3} / \mathrm{s}\right)$ & 0.02832 & cubic meter per second $\left(\mathrm{m}^{3} / \mathrm{s}\right)$ \\
\hline \multicolumn{3}{|l|}{$\underline{\text { SI to Inch/Pound }}$} \\
\hline Multiply & By & To obtain \\
\hline \multicolumn{3}{|c|}{ Length } \\
\hline centimeter $(\mathrm{cm})$ & 0.3937 & inch (in.) \\
\hline millimeter (mm) & 0.03937 & inch (in.) \\
\hline
\end{tabular}


This page left intentionally blank 


\title{
Evaluation of the Behavior and Movement of Adult Summer Steelhead in the Lower Cowlitz River, Washington, Following Collection and Release, 2013-2014
}

\author{
By Tobias J. Kock ${ }^{1}$ Theresa L. Liedtke¹, Brian K. Ekstrom¹ , Chris Gleizes², and Wolf Dammers²
}

\section{Executive Summary}

Summer steelhead (Oncorhynchus mykiss) produced by a hatchery on the lower Cowlitz River, Washington, support a popular sport fishery during June-September each year. Many of these fish return to the Cowlitz Salmon Hatchery and are held until they are spawned in December. In the past, fishery managers have released some of the steelhead that return to the hatchery at downstream release sites (hereafter referred to as "recycled steelhead") to increase angling opportunity. The recycling of summer steelhead is a potential use of hatchery fish that can benefit anglers in the lower Cowlitz River, provided these fish are harvested or return to the hatchery. However, recycled steelhead that are not removed from the river could compete against or spawn with wild winter steelhead, which would be a negative consequence of recycling. The Washington Department of Fish and Wildlife (WDFW) conducted an evaluation during 1998 and recycled 632 summer steelhead. They determined that 55 percent of the recycled steelhead returned to the hatchery and 15 percent of the fish were harvested by anglers. The remaining 30 percent of recycled fish were not known to have been removed from the river. Recycling has not occurred in recent years because definitive studies have not been conducted to determine the fate of the fish that remain in the lower Cowlitz River after being recycled.

The U.S. Geological Survey and WDFW conducted a 2-year study during 2012-2014 to quantify recycled steelhead that (1) returned to the hatchery, (2) were captured by anglers, or (3) remained in the river. All recycled steelhead were marked with a Floy ${ }^{\circledR}$ tag and opercle punch, and 20 percent of the recycled fish were radio-tagged to determine post-release behavior and movement patterns, and to describe locations of tagged fish that remained in the river during the spawning period. During 2012-2013, we recycled 549 steelhead and determined that 50 percent of the fish returned to the hatchery, 18 percent of the fish were harvested by anglers, and 32 percent of the fish were not known to have been removed from the river. During October-December 2012, only 9 percent of the radio-tagged steelhead remained in the lower Cowlitz River and none of these fish entered tributaries monitored by fixed-telemetry sites.

\footnotetext{
${ }^{1}$ U.S. Geological Survey.

${ }^{2}$ Washington Department of Fish and Wildlife.
} 
The second year of the evaluation was conducted during 2013-2014. A total of 502 steelhead were recycled during June-August and releases were conducted weekly with group sizes that ranged from 30 to 76 fish. Results from 2013-2014 were similar to results from 2012-2013. Fifty percent (251 fish) of the recycled steelhead returned to the hatchery, 20 percent (100 fish) were harvested by anglers, and 30 percent (151 fish) were unaccounted for. The median elapsed time from release to hatchery return was 13 days, and the median elapsed time from release to capture by an angler was 11 days. The percentage of unaccounted-for steelhead in the general population was moderately high (30 percent), but detection records of radio-tagged fish suggest that few recycled steelhead were present in the lower Cowlitz River during the spawning period.

A total of 109 steelhead were radio-tagged during 2013-2014, and most of these fish (88 percent) moved upstream following release and entered the Trout Hatchery-Salmon Hatchery reach (river miles 44-51). The median elapsed time from release to reach entry was 4.6 days (range of $0.5-$ 65.5 days). After fish entered this reach, they spent a considerable amount of time near the Cowlitz Trout Hatchery (median residence time of 16.7 hours) or Cowlitz Salmon Hatchery (median residence time of 146.3 hours), or they moved back and forth between these two sites. Thirty radio-tagged steelhead made at least two trips between the sites and some fish made as many as seven trips. Detection records showed that 61 percent (66 fish) of the radio-tagged fish returned to the hatchery reach and 21 percent ( $23 \mathrm{fish}$ ) of the fish were captured by anglers. The remaining 18 percent ( 20 fish) of the radiotagged fish had various fates. One fish (less than 1 percent) left the Cowlitz River and nine fish (8 percent) died, were harvested, or spit their transmitter near boat launches in the river. The remaining 10 fish ( 9 percent) had the potential to interact with winter steelhead. Four tagged steelhead (4 percent) entered lower Cowlitz River tributaries (two fish in the Toutle River; two fish in Salmon Creek) during October and November, and five tagged fish ( 5 percent) were last detected in the lower Cowlitz River in October. One fish (less than 1 percent) was never detected after being released.

We measured the diameter of opercle punches in recycled steelhead to determine the temporal effectiveness of these marks. A total of 116 opercle punches were measured-36 were measured at the time of tagging and 80 were measured when fish returned to the hatchery. Opercle punches remained open for less than 1 month. None of the fish that returned to the hatchery more than 30 days after release had opercle punches that were open. All recycled steelhead were marked with a Floy ${ }^{\circledR}$ tag and opercle punch. However, if a steelhead lost its Floy ${ }^{\circledR}$ tag and was captured by an angler, or returned to the hatchery more than 30 days after being recycled, it likely would not have been accurately identified as having been recycled because of regrowth of the opercle punch.

During 2013-2014, at least 70 percent of the recycled steelhead were removed from the lower Cowlitz River by anglers, returned to the hatchery, or left the river. Radiotelemetry data indicated that a maximum of 9 percent of the radio-tagged fish remained in the lower Cowlitz River during the spawning period and only 4 percent of the radio-tagged fish entered tributaries where wild steelhead are known to spawn. These results are consistent with findings from previous studies. Overall, results from these studies suggest that about one-third of the recycled steelhead were not known to have been removed from the river. However, the radiotelemetry data indicated that only about 10 percent of the recycled steelhead were present in the lower Cowlitz River during late autumn and early winter, and few of those fish (0 in 2012-2013 and 4 in 2013-2014) entered tributaries where winter steelhead spawn. These results have management implications in the lower Cowlitz River where the risks and rewards of steelhead recycling will be weighed to determine the future of the recycling program. 


\section{Introduction}

Steelhead (Oncorhynchus mykiss) are an important resource in the Cowlitz River, a primary tributary to the lower Columbia River in southwestern Washington State. The Cowlitz River supports three steelhead populations - a hatchery summer run, a hatchery winter run, and a wild winter run. For this report, only the hatchery summer run (hereafter referred to as "summer steelhead") and the wild winter run (hereafter referred to as "winter steelhead") will be discussed. Summer steelhead return to the Cowlitz River during May-October and typically spend several months in the system before they are spawned in the hatchery during December and January. Winter steelhead return to the river during February-April and spawn in tributaries during the spring (March-May). Summer steelhead populations are maintained by hatchery production to support a popular sport fishery, whereas the winter steelhead population currently is listed as threatened under the Endangered Species Act of 1973 (National Marine Fisheries Service, 2011).

Steelhead recycling is one activity that has been used previously to increase angling opportunity in the lower Cowlitz River. The recycling program consisted of collecting and marking (with an opercle punch) adult steelhead that returned to the Cowlitz Trout and Salmon Hatcheries (fig. 1) prior to the spawning period and releasing them back into the river where anglers had another opportunity to harvest those fish. In 1998, the Washington Department of Fish and Wildlife (WDFW) conducted a study to determine the fate of recycled steelhead in the lower Cowlitz River. Of the 632 steelhead that were recycled, 55 percent of the fish returned to the hatcheries, and 15 percent of the fish were captured by anglers (Tipping, 1998). The remaining steelhead (30 percent) were not known to have been removed from the river (Tipping, 1998), and thus represented a threat to wild fish because it was possible for them to spawn with or compete against wild winter steelhead in the system. Because of this risk, and the lack of definitive studies to address the potential interactions between recycled steelhead and wild steelhead, recycling has not occurred in the Cowlitz River during recent years.

A 2-year evaluation was initiated in 2012 on the lower Cowlitz River to further assess summer steelhead recycling. The goals of this study were to monitor the behavior and movement of recycled steelhead and to quantify fish that returned to the hatchery, were captured by anglers, or remained in the Cowlitz River (or a tributary of the Cowlitz River). A total of 549 summer steelhead were recycled during the first year (2012-2013). All recycled steelhead were marked with a Floy ${ }^{\circledR}$ tag and opercle punch, and one in five recycled fish were tagged with a radio transmitter. Based on recapture data and telemetry detection records, an estimated 50 percent of the recycled fish returned to the hatchery, 18 percent were captured by anglers, and 32 percent were not known to have been removed from the river (Kock and others, 2013). However, 109 of the recycled steelhead were tagged with a radio transmitter to monitor movements of recycled fish during the spawning period and to determine when interactions with wild fish would be possible. Twelve percent of radio-tagged steelhead were present in the lower Cowlitz River during October 2012-January 2013 (Kock and others, 2013). Only one radio-tagged steelhead entered a tributary of the Cowlitz River during the first year of the study. This fish entered and then exited the Toutle River within a 1-week period during August-September, well before the December spawning period. 
This study relied on the ability to identify recycled steelhead based on the presence of marks and tags (opercle punch, Floy ${ }^{\circledR}$ tag, radio transmitter) when those fish were captured or returned to the hatchery, so tag loss was an important factor to understand. The loss of Floy ${ }^{\circledR}$ tags and radio transmitters could be assessed directly because these tags and transmitters were either present or absent when fish were encountered by anglers or hatchery staff. However, opercle punches change temporally as tissue regrows. Opercle punches are popular fish-marking techniques because they are inexpensive and can be easily identified when fish are handled and visually examined. Although opercle punches are commonly used, there is little information on regrowth rates; therefore, we collected data during this study to better understand the temporal effectiveness of the mark. During 2012-2013, opercle punches in recycled steelhead remained open for less than 30 days. We continued this component of the evaluation during the second year of research, and the results of the 2013-2014 evaluation are presented in this report.

\section{Methods}

\section{Fish Tagging and Release}

A total of 502 adult summer steelhead were collected at the Cowlitz Salmon Hatchery (river mile [rm] 51; fig. 1), tagged, and then transported downstream and released in the lower Cowlitz River. Each fish was tagged with two white Floy ${ }^{\circledR}$ tags (Model FD-68BC, Floy Tag, Inc., Seattle, Washington) near the dorsal fin, and a single 6-mm diameter hole was created in the operculum on the right side of the fish (hereafter referred to as "opercle punch") using a hand punch (fig. 2). We also tagged 109 (22 percent) of these fish with a radio transmitter (Model Pices, Sigma Eight, Inc., Newmarket, Ontario; or Model MCFT2-3EM, Lotek Wireless, Inc., Newmarket, Ontario) to monitor behavior and movement patterns during the study. A total of nine tagging and release efforts were conducted during JuneAugust 2013 (table 1). On each tagging date, adult summer steelhead were collected by hatchery staff as part of the daily collection process. Groups of about 20 fish were crowded into a large basket and anesthetized using an electroanesthesia system. Each group of fish then was sorted and summer steelhead were selected for tagging if they had not previously been tagged. Each fish was measured for fork length to the nearest centimeter, visually categorized as male or female, and then Floy ${ }^{\circledR}$-tagged and opercle-punched. Fish that received radio transmitters were tagged (while under sedation) at this time as well. Radio transmitters were implanted gastrically using procedures describe by Keefer and others (2004). Tagged fish then were placed into a hatchery holding tank where they were held for about 24 hours. On each release date, tagged fish were loaded into large fish-hauling trucks and transported downstream where they were released at the Interstate 5 boat launch (rm 30; fig. 1).

The temporal retention of opercle punches was assessed using (1) steelhead that were tagged prior to recycling, and (2) steelhead that returned to the hatchery after being recycled. Individual steelhead were photographed immediately after tagging and when they returned to the hatchery, and we used the Image Pro Plus (Version 4.5; Media Cybernetics, Inc.; Rockville, Maryland) software program to digitally measure the diameter of each opercle punch. These measurements were paired with Floy ${ }^{\circledR}$ tag identification numbers so that we could determine the elapsed time from tagging for fish that were measured at the time of recollection. 


\section{River Flow}

Daily river flows (measured near Mayfield Dam; U.S. Geological Survey streamgage No. 14238000) were collected and a daily flow ratio statistic was calculated to determine how river flows in 2013 compared to average river flows during 2008-2012. The mean daily flow for each date during June-December 2013 was divided by the mean daily flow for individual dates from 2008 to 2012 to obtain a daily flow ratio value. For example, average river flows on October 3, 2013, were 10,300 $\mathrm{ft}^{3} / \mathrm{s}$ and the average flow on October 3 during 2008-2012 was 5,032 $\mathrm{ft}^{3} / \mathrm{s}$. The ratio was calculated as $10,300 / 5,032=2.05$, which indicates that river flows on October 3,2013 , were about twice as high as average during 2008-2012. Daily flow ratio values were plotted for the study period to assess if 20132014 river flows were typical compared to previous years.

\section{Fish Monitoring}

We collected data on recycled steelhead using three primary approaches during 2013-2014. These included (1) monitoring at the hatchery to quantify recollected recycled steelhead, (2) conducting a creel survey and collecting voluntary angler reports to quantify recycled steelhead that were captured by anglers, and (3) monitoring movements of radio-tagged fish through fixed-monitoring sites (hereafter referred to as "fixed sites") and mobile tracking.

The fish trap at the Cowlitz Salmon Hatchery is operated 5 days per week (Monday-Friday) and hatchery personnel examined summer steelhead that were captured in the trap during June-December 2013 to identify recycled fish. Recycled steelhead were identified by the presence of at least one of the three tags or marks (that is, white Floy ${ }^{\circledR}$ tag, opercle punch, and radio transmitter) used during the study. When recycled steelhead were observed at the hatchery, the Floy ${ }^{\circledR}$ tag and radio transmitter (when present) were removed and the identification numbers and recapture date were recorded. If a recycled steelhead returned without a Floy ${ }^{\circledR}$ tag or radio transmitter (identified by the opercle punch only), then only the recapture date was recorded. Recycled steelhead that were present in the fish trap were retained at the Cowlitz Salmon Hatchery and were not re-released into the lower Cowlitz River.

Data were collected through a creel survey and voluntary angler reporting to quantify recycled steelhead that were captured in the fishery during the study. The creel survey was conducted during June 2013-January 2014. Angling is popular throughout the lower Cowlitz River, so we attempted to visit multiple sites on each survey date to maximize the number of anglers interviewed and to account for spatial differences in harvest. Creel surveys targeted popular fishing locations in the lower Cowlitz

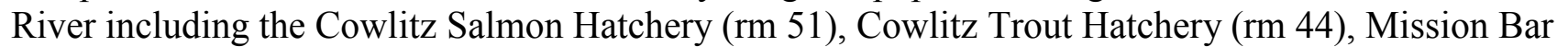

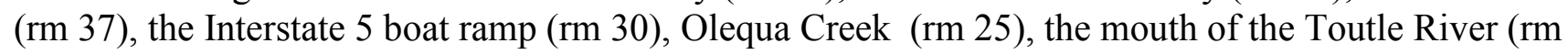
20), the town of Castle Rock (rm 17), and Camelot (rm 15). Anglers were interviewed to determine the number of hours fished and the number of fish that were captured. Adult steelhead that were retained by anglers were enumerated, and recycled steelhead were identified and enumerated using criteria previously described. We also distributed information about the study to local fishing shops, on regional fishing websites, and at popular boat launches and fishing locations so anglers could voluntarily report information when recycled steelhead were captured. 
We established five fixed sites on the main-stem Cowlitz River and seven fixed sites on tributaries to the lower Cowlitz River to monitor behavior and movement patterns of radio-tagged steelhead. Main-stem fixed sites were at the Cowlitz Salmon Hatchery, the Cowlitz Trout Hatchery, just upstream of the Interstate 5 boat ramp, near the mouth of the Toutle River, and near the mouth of the Cowlitz River (rm 1; fig. 1). Tributary fixed sites were established on Salmon Creek, Lacamas Creek, Olequa Creek, the Toutle River, at the confluence of Arkansas and Delameter Creeks, Ostrander Creek, and the Coweeman River (fig. 1). Fixed sites continuously monitored for the presence of tagged fish from June 2013 to February 2014. To supplement fixed-site detections, we conducted six mobile tracking surveys. Boat mobile-tracking surveys were conducted from the Cowlitz Salmon Hatchery to Longview, Washington, on October 25, 2013, November 21, 2013, November 26, 2013, December 4, 2013, and January 22, 2014. Mobile tracking was conducted from an automobile on December 18, 2013, and focused on tributary areas in the lower Cowlitz River.

\section{Results}

\section{Run Size and Run Timing}

A total of 3,882 summer steelhead were collected at the Cowlitz Salmon Hatchery during AprilDecember 2013, which is less than the 10-year average. During 2002-2013, annual collection of summer steelhead adults at the Cowlitz Salmon Hatchery averaged 6,597 fish and ranged from a minimum of 1,355 fish in 2001 to a maximum of 10,895 fish in 2012. In 2013, most fish (91 percent) were collected during June-September, but some fish were collected into November.

\section{River Flows}

River flows generally decreased from about $6,000 \mathrm{ft}^{3} / \mathrm{s}$ in June to about $3,000 \mathrm{ft}^{3} / \mathrm{s}$ in August (fig. 3). River flows then generally increased from September to December. Two major flow events occurred during the study, one in early October and one in late November (fig. 3). The daily flow ratio values indicated that flows in 2013 were below normal during most of the summer and early autumn (June-September), and then were near normal or above normal during the autumn and early winter (October-December; fig. 3).

\section{Fate of Recycled Steelhead}

Seventy percent of the recycled steelhead were removed from the lower Cowlitz River prior to the December spawning period. A total of 502 steelhead were recycled. Of these fish, 251 (50 percent) eventually returned to the hatchery and 100 were captured by anglers ( 20 percent) (table 2 ). The whereabouts of the remaining 151 fish ( 30 percent) were unknown; therefore, these fish were assumed to have remained in the river (table 2). The median elapsed time from release to hatchery return was 13 days (range of 3-138 days), compared to 11 days (range of 0-172 days) for fish that were captured by anglers. Most fish that returned to the hatchery or were captured by anglers did so during JulySeptember (fig. 4). The pattern of fates for weekly release groups generally was similar throughout the study period - the largest percentage of recycled fish returned to the hatchery (fig. 5). 


\section{Radiotelemetry}

Movement patterns of radio-tagged fish showed that most recycled steelhead moved upstream of the release site shortly after they were returned to the river. Following release, 96 tagged steelhead (88 percent) moved upstream and entered the Trout Hatchery-Salmon Hatchery reach. The median elapsed time from release to first detection in the reach was 4.6 days (range of 0.5-65.5 days). Many of the fish that entered the Trout Hatchery-Salmon Hatchery reach made multiple trips between the two sites (fig. 6). The Cowlitz Trout and Salmon Hatcheries are popular steelhead fishing locations; radio-tagged steelhead spent a considerable amount of time at these sites. The median in-river residence time for radio-tagged steelhead at the Cowlitz Trout Hatchery was 16.7 hours (range of 0.1-3,014.7 hours), and the median residence time at the Cowlitz Salmon Hatchery was 146.3 hours (range of 0.1-2,649.9 hours).

Radio-tagged fish provided valuable information because we were able to determine the fates of fish that were not removed from the river, to monitor tributaries for the presence of tagged fish, and to describe behavior patterns of fish prior to entering the hatchery or being captured by anglers. A total of 109 recycled steelhead were radio-tagged in 2013. The largest percentage of radio-tagged fish returned to the hatchery (66 fish; 61 percent), whereas the remaining fish either were captured by anglers (23 fish; 21 percent), or were not known to have been removed from the river (20 fish; 18 percent) (table 2). We examined detection histories of the 20 radio-tagged steelhead that were not known to have been removed from the river to determine where they were during September-January, which is the period when recycled steelhead would be staging to spawn and spawning. Ten of these fish ( 9 percent) had detection histories that indicated they would not have posed a risk to wild steelhead in the lower Cowlitz River. Nine of these 10 tagged fish were detected repeatedly at the same locations by mobile trackers during autumn 2013 - five fish were near the Blue Creek boat launch, three fish were near the Interstate 5 boat launch, and one fish was near the Castle Rock boat launch (table 2). These fish did not move after they initially were detected at these locations in October, which indicates that they died naturally, they were harvested and the tag was discarded, or they spit their transmitter. The last fish in this group that did not pose a risk to wild fish in the lower Cowlitz River was detected leaving the river on October 21, 2013, and was later detected in the Kalama River.

The detection histories for the remaining 10 fish indicated that they may have posed a risk to wild steelhead in the lower Cowlitz River. Four tagged steelhead (4 percent) entered a Cowlitz River tributary (table 2). Two of these fish entered Salmon Creek and the other two fish entered the Toutle River. Three of the these fish entered the tributaries in early October and the fourth fish entered Salmon Creek in mid-November. Additionally, five fish (5 percent; table 2) were last detected in the Cowlitz River during late September or October, and the remaining one fish was never detected during the study period. It is possible that these fish entered a Cowlitz River tributary, remained in the Cowlitz River, or were removed from the river. However, because they were not detected after October, they could not be eliminated as potential risks to wild steelhead in the river. 


\section{Temporal Effectiveness of Opercle Punches}

We measured 116 opercle punches during the study period and determined that the opercle punches remained open for less than 1 month (fig. 7). Opercle punch measurements were taken at the time of tagging (36 fish) and when fish returned to the hatchery (80 fish). The diameter of the opercle hole was plotted against the elapsed time since tagging (fig. 7). In general, the diameter of the opercle punch did not change substantially during the first 20 days following tagging, but the hole closed quickly between 20 and 30 days after tagging. All steelhead that returned to the hatchery more than 30 days after tagging had opercle punches that had completely closed.

\section{Discussion}

Summer steelhead recycling has been the focus of several evaluations in the lower Cowlitz River since the mid-1990s, and results from these studies suggest that the distributions of hatchery return, angler harvest, and unaccounted-for fates are consistent among years. The Tipping (1998) evaluation included 632 steelhead, and our evaluations included 549 and 502 steelhead in 2012 and 2013, respectively (Kock and others, 2013). All three studies noted that trends in fish fates were similarabout one-half of the recycled fish returned to the hatchery (55 percent in 1998, 50 percent in 2012, and 50 percent in 2013), about one-fifth of the recycled fish were captured by anglers (14 percent in 1998 , 18 percent in 2012, and 20 percent in 2013), and about one-third of the recycled fish were not known to have been removed from the river (31 percent in 1998, 32 percent in 2012, and 30 percent in 2013). These results were consistent and suggest that the mechanisms responsible for each of the fate groups vary little from year to year in the lower Cowlitz River.

The goal of recycling fish is to increase angling opportunity, but hatchery return is an acceptable fate as well because these fish are removed from the river and do not pose a risk to wild fish in the system. During this study, anglers harvested 18-20 percent of the recycled steelhead, but at least 68-70 percent of the recycled fish were removed from the river because 50 percent of the recycled steelhead returned to the hatchery. In comparison, steelhead recycling in the Siuslaw and Willamette Rivers in Oregon, resulted in lower catch rates and fewer fish returning to hatchery fish traps (Lindsay and others, 2001; Jepson and others, 2013). During a 3-year study in the Siuslaw River, anglers captured an average of 11 percent of the recycled steelhead and less than one-half (44 percent) of all recycled fish were known to have been removed from the river by anglers and fish traps combined (Lindsay and others, 2001). Similarly, Jepson and others (2012) noted that anglers in the Willamette River captured 4-17 percent of the steelhead that were recycled during their study period, and only 26-38 percent of the recycled fish were known to have been removed from the river. The number of recycled fish that are unaccounted for is the largest obstacle to continued recycling because studies have shown that wild steelhead populations are negatively influenced when interbreeding with hatchery steelhead occurs (Chilcote, 2003; Kostow and others, 2003)

Recycled steelhead that were not known to have been removed from the river in this study may have had a variety of fates that would have eliminated them as potential threats to wild steelhead in the system. These potential fates include (1) fish that were captured by anglers but not reported, (2) fish that left the Cowlitz River, (3) fish that died in the Cowlitz River prior to the spawning period, and (4) fish that were recovered but were not identified as recycled fish due to missing marks. Voluntary angler reporting was used as the primary method for estimating angler harvest during this study. In several other studies, however, this method has been shown to underestimate true harvest rates (Green and others, 1983; Bray and Schramm, 2001; McCormick and others, 2013). Additionally, some recycled steelhead may have left the lower Cowlitz River after being recycled. For example, one of the radio- 
tagged steelhead was detected leaving the Cowlitz River in October 2013, and later was detected in the Kalama River. Similarly, Tipping (1998) found that five recycled steelhead from his study later were recovered in the North Fork Lewis River or Kalama River. Fish that died in the Cowlitz River during June-November would not pose a risk to wild steelhead. During 2012-2014, we determined that 8-10 percent of the recycled steelhead that were radio-tagged either spit their transmitter, died, or had their transmitter removed and discarded near popular boat launches (Blue Creek, Mission Bar, Toledo, and Interstate 5 boat launches). Finally, tag loss likely was a contributing factor to the percentage of unaccounted-for fish in this study. Floy ${ }^{\circledR}$ tags and opercle punches are passive fish-marking techniques which means that anglers and hatchery workers had to observe the marks and report that individual fish were removed from the river. In the event that marks were missing or not observed, recycled fish were considered to be unaccounted for. Floy ${ }^{\circledR}$ tag loss has been well documented (Smith and McPherson, 1981; Mourning and others, 1994; Nuhfer and others, 1996), and 6 percent of the recycled steelhead that returned to the hatchery in 2012, when fish were tagged with a single Floy ${ }^{\circledR}$ tag, were missing their Floy ${ }^{\circledR}$ tag (Kock and others, 2013). We also determined that opercle punches remained open for less than 30 days. Given this observation, recycled steelhead that lost their Floy ${ }^{\circledR}$ tag and returned to the hatchery or were captured by anglers more than 30 days after being released would not have been identified as a recycled fish. The scenarios discussed above were possible for recycled steelhead that were unaccounted for in this study, and if some of these fish experienced those fates, then this study would have overestimated the true number of recycled fish that potentially were available to interact with wild steelhead. This statement is supported by data from radio-tagged fish.

The number of radio-tagged steelhead that remained in the lower Cowlitz River during the spawning period was low and very few radio-tagged fish entered tributaries where wild steelhead are known to spawn. Detection records during October-January indicated that 9-12 percent of the radiotagged steelhead remained in the lower Cowlitz River during 2012-2014. None of the radio-tagged steelhead entered tributaries during October 2012-January 2013. However, four radio-tagged fish (4 percent) entered lower Cowlitz River tributaries in 2013-2014. These data suggest that tributary entry events by recycled steelhead could vary among years, but overall tributary use by these fish appears to be low.

Movement patterns of radio-tagged steelhead shortly after release showed that recycled steelhead responded in a manner that would make them susceptible to anglers. Most radio-tagged steelhead moved upstream and entered the Trout Hatchery-Salmon Hatchery reach shortly after release. During 2012-2013, 82 percent of the radio-tagged fish entered this reach, and the median travel time was 3.7 days (Kock and others, 2013). Results from 2013-2014 were similar; 88 percent of the fish moved upstream and entered the reach with a median travel time of 4.6 days. The percentage of tagged fish that moved upstream would have been higher, but some recycled steelhead were captured near the release site, downstream of the reach, or within 3 days of release. This movement pattern is important because many of the popular fishing areas on the lower Cowlitz River are upstream of the Interstate 5 boat launch, and most of the tributaries used by wild steelhead are downstream of the release site. Tagged fish that entered the Trout Hatchery-Salmon Hatchery reach showed a strong affinity for the reach. Many fish made multiple trips between the two locations or spent a considerable amount of time near the Cowlitz Trout and Salmon Hatcheries (median residence times were 16.7 hours and 146.3 hours, respectively), where angling pressure is high. This behavior was ideal for the recycling program because it showed that recycled fish spent most of their time in a reach of the river where angling pressure is high and where fish could easily return to the hatchery. 
In summary, the data collected during this 2-year study indicated that many steelhead were removed from the lower Cowlitz River after being recycled. These results are consistent with the Tipping (1998) study, which was conducted more than a decade prior to this study. Overall, about onethird of the recycled steelhead were unaccounted for at the conclusion of this study. However, data from radio-tagged steelhead suggest that few fish remain in the lower Cowlitz River or in one of its tributaries during the December-January spawning period for hatchery summer steelhead. We did not evaluate if these fish remained in the system during March-May when wild winter steelhead are spawning. Recycling summer steelhead can be used to supplement angling opportunities for a highly valued fish species in the lower Cowlitz River. However, this activity also may lead to increased risk to wild fish in the system. Results from this study should be useful for assessing the potential risks and rewards associated with recycling steelhead in the future.

\section{Acknowledgments}

This research was funded by the Washington Department of Fish and Wildlife with funds provided through the Columbia River Salmon and Steelhead Endorsement Program. Transportation of tagged fish from the hatchery to the release site was conducted by Tacoma Power. We are grateful to Mike Blankenship, Teresa Fryer, John Serl, and Wade Heimbigner with the Washington Department of Fish and Wildlife and the Pacific States Marine Fisheries Commission for their contributions during the study. Similarly, Jamie Murphy, Scott Gibson, and Missy Baier with Tacoma Power provided assistance with fish collection and handling at the Cowlitz Salmon Hatchery. Chris Karchesky and Jill Hardiman reviewed the report and provided editorial comments that improved the document. We thank both of them for their efforts.

\section{References Cited}

Bray, G.S., and Schramm, H.L, Jr., 2001, Evaluation of a statewide volunteer angler diary program for use as a fishery assessment tool: North American Journal of Fisheries Management, v. 21, p. 606615.

Chilcote, M.W., 2003, Relationship between natural productivity and the frequency of wild fish in mixed spawning populations of wild and hatchery steelhead (Oncorhynchus mykiss): Canadian Journal of Fisheries and Aquatic Sciences, v. 60, p. 1057-1067.

Green, A.W., Matlock, G.C., and Weaver, J.E., 1983, A method for directly estimating the tag-reporting rate of anglers: Transactions of the American Fisheries Society, v. 112, p. 412-415.

Jepson, M.A., Keefer, M.A., Clabough, T.S., and Caudill, C.C., 2013, Migratory behavior, run timing, and distribution of radio-tagged adult winter steelhead, summer steelhead, and spring Chinook salmon in the Willamette River, 2012: Technical Report 2013-1 for the U.S. Army Corps of Engineers, Portland, Oregon.

Keefer, M.L., Peery, C.A., Ringe, R.R., and Bjornn, T.C., 2004, Regurgitation rates of intragastric radio transmitters by adult Chinook salmon and steelhead during upstream migration on the Columbia and Snake Rivers: Transactions of the American Fisheries Society, v. 24, p. 47-54.

Kock, T.J., Liedtke, T.L., Ekstrom, B.K., Rondorf, D.W., Gleizes, C., Dammers, W., Gibson, S., and Murphy, J., 2013, Behavior and movement of adult summer steelhead following collection and release, lower Cowlitz River, Washington 2012-2013: U.S. Geological Survey Open-File Report 2013-1116, 22 p. 
Kostow, K.E., Marshall, A.R., and Phelps, S.R., 2003, Naturally spawning hatchery steelhead contribute to smolt production but experience low reproductive success, v. 132, p. 780-790.

Lindsay, R.B., Kenaston, K.R., and Schroeder, K.R., 2001, Reducing the impacts of hatchery steelhead programs on wild steelhead: Portland, Oregon Department of Fish and Wildlife Information Reports, Number 2001-01.

McCormick, J.L., Quist, M.C., and Schill, D.J., 2013, Self-reporting bias in Chinook salmon sport fisheries in Idaho-Implications for roving creel surveys: North American Journal of Fisheries Management, v. 33, p. 723-731.

Mourning, T.E., Fausch, K.D., and Gowan, C., 1994, Comparison of visible implant tags and Floy ${ }^{\circledR}$ anchor tags on hatchery rainbow trout: North American Journal of Fisheries Management, v. 14, p. 636-642.

National Marine Fisheries Service, 2011, 5-year review-Summary and evaluation of lower Columbia River Chinook, Columbia River chum, lower Columbia River coho and lower Columbia River steelhead: National Oceanic and Atmospheric Administration, National Marine Fisheries Service NMFS-NWFSC Status Review Update Memo, July 26, 2011, 53 p.

Nuhfer, A.J., Lockwood, R.N., and Dexter, J.L., Jr., 1996, Selected factors affecting rate of loss of finefabric Floy ${ }^{\circledR}$ tags when applied to yearling brown and rainbow trout: Michigan Department of Natural Resources Fisheries Research Report Number 2025.

Smith, A.K., and McPherson, B.P., 1981, Comparison of T-bar and Petersen disc tag loss from Chinook salmon (Oncorhynchus tshawytscha) in the Rogue River, Oregon: Portland, Oregon Department of Fish and Wildlife Report 80-8.

Tipping, J.M., 1998, Summer steelhead recycling experiment: Washington State Department of Fish and Wildlife Report Number 99-01. 


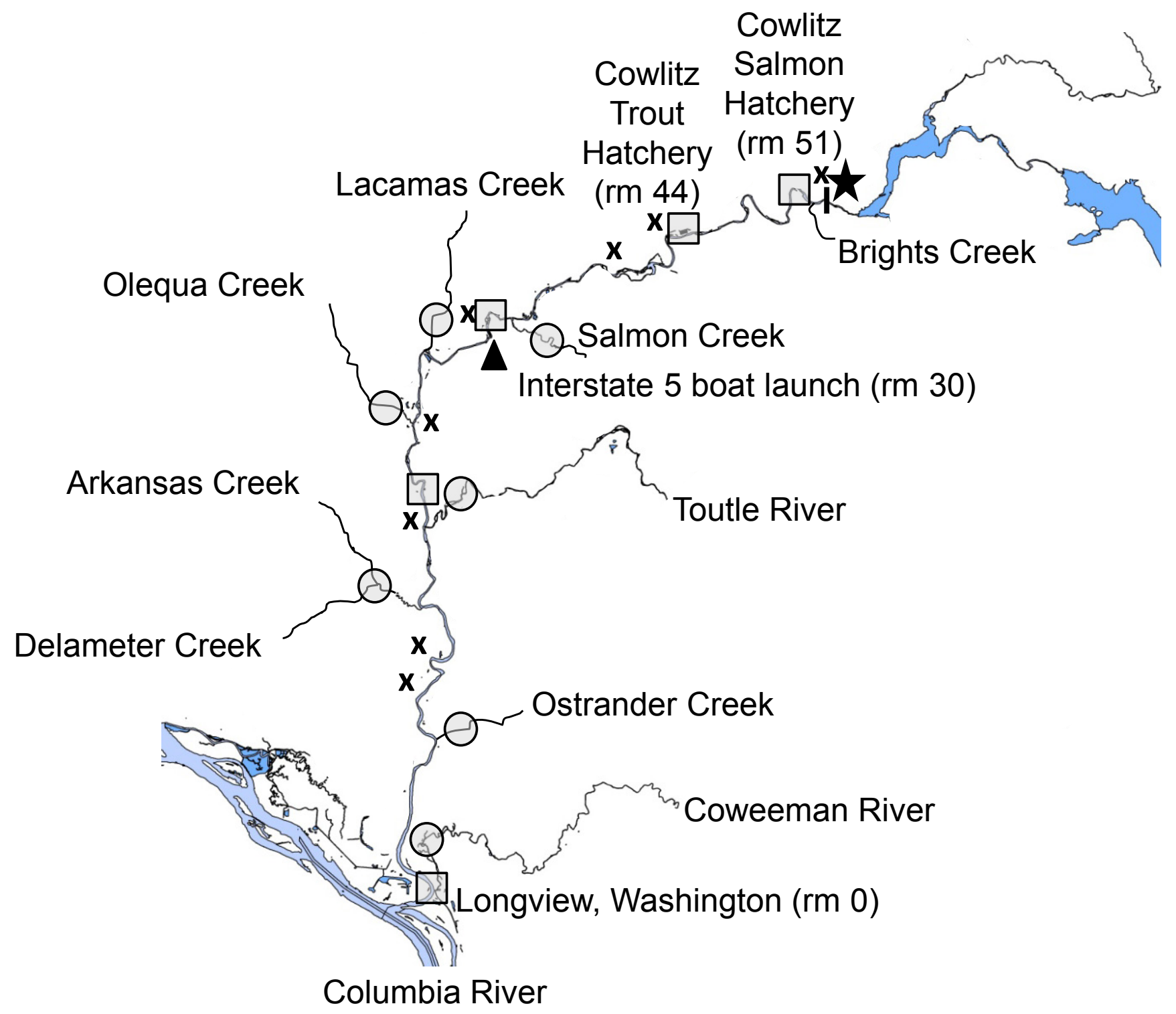

Figure 1. Schematic of lower Cowlitz River, Washington, showing where recycled steelhead were tagged (star) and released (triangle). Locations of fixed sites that monitored the main stem Cowlitz River (squares) and tributaries (circles) for radio-tagged fish also are shown. Creel survey locations are identified by the letter " $x$ ". 


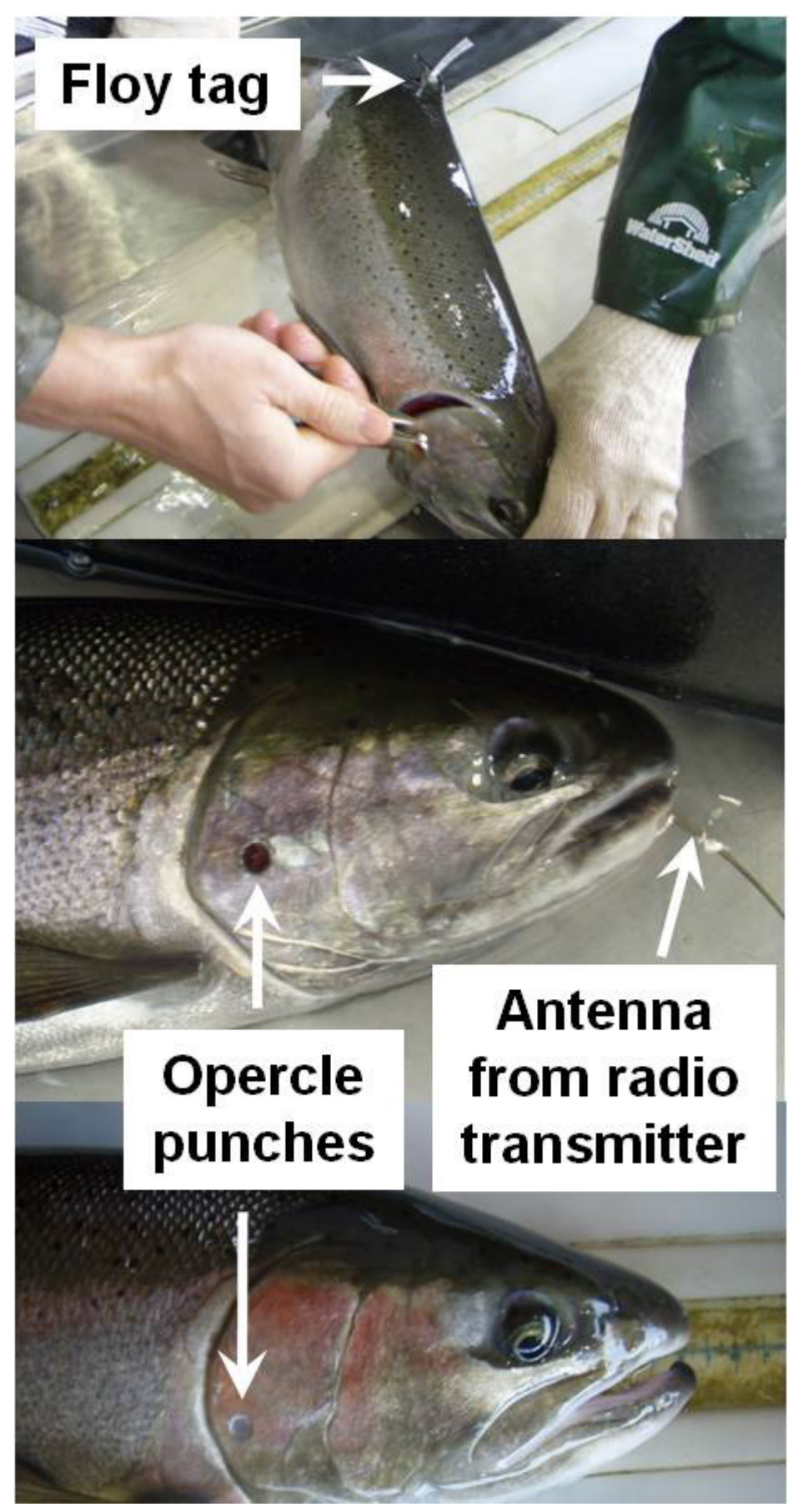

Figure 2. Photographs showing a Floy ${ }^{\circledR}$-tagged steelhead that was being opercle-punched (top); a fresh opercle punch and a radio transmitter antenna exiting the fish mouth (transmitter was located inside the fish and is not visible) (middle); and an opercle punch that had closed from tissue re-growth (bottom). Photographs taken by Tobias J. Kock, U.S. Geological Survey, July 23, 2012. 

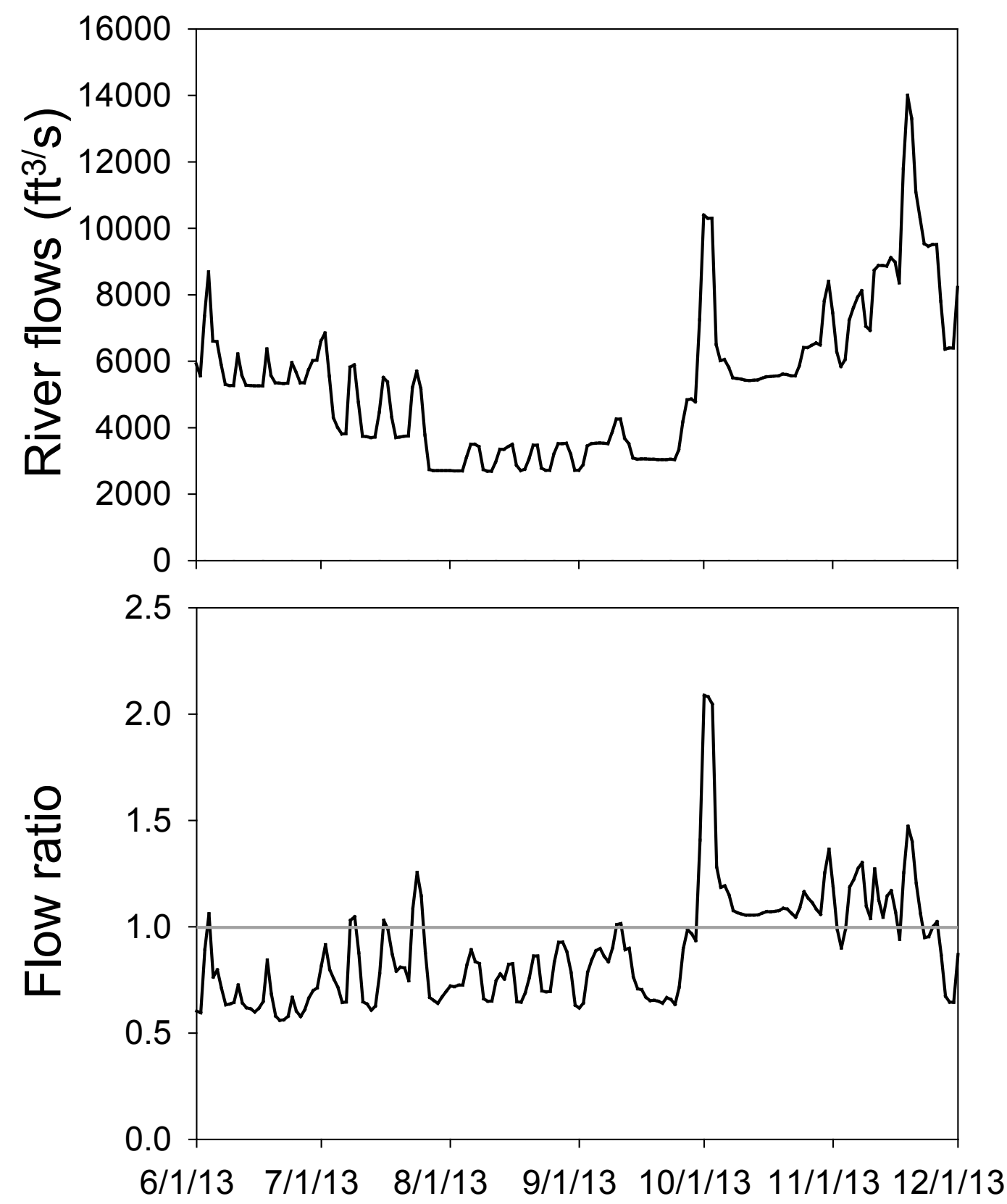

Figure 3. Graphs showing daily river flows (in cubic feet per second [ft3/s]; top) near Mayfield Dam (U.S. Geological Survey streamgage No. 14238000) during June-December 2013, and the relation (ratio) between 2013 and average 2008-2012 flows (bottom), lower Cowlitz River, Washington. Flow ratio of 1.0 indicates that 2013 flows were identical to average 2008-2012 flows. Flow ratios less than 1.0 indicate that 2013 flows were less than 2008-2012 flows, and flow ratios greater than 1.0 indicate that 2013 flows were greater than 2008-2012 flows. 


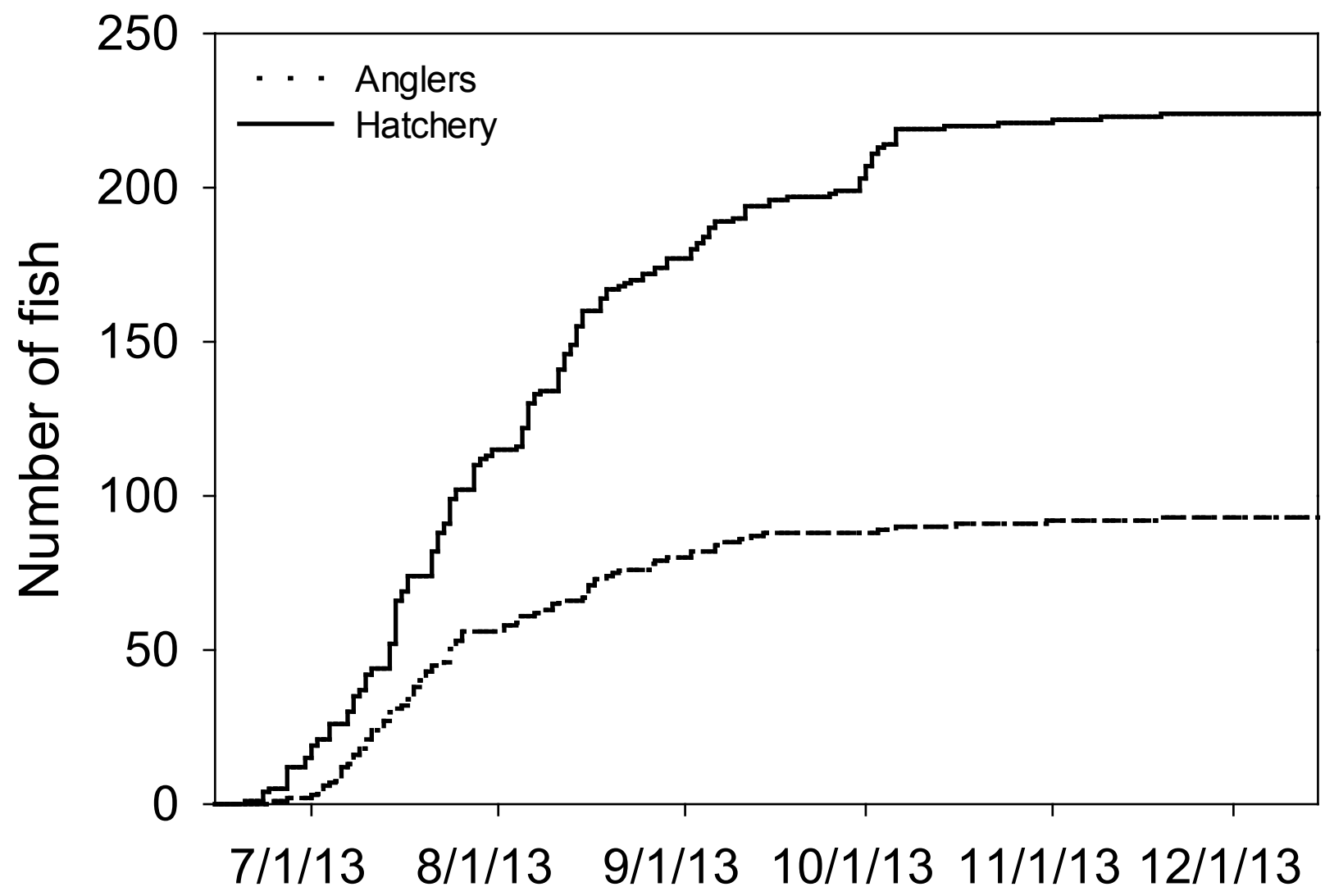

Figure 4. Graph showing cumulative number of recycled steelhead that were captured by anglers or returned to Cowlitz Salmon Hatchery, lower Cowlitz River, Washington, 2013. 


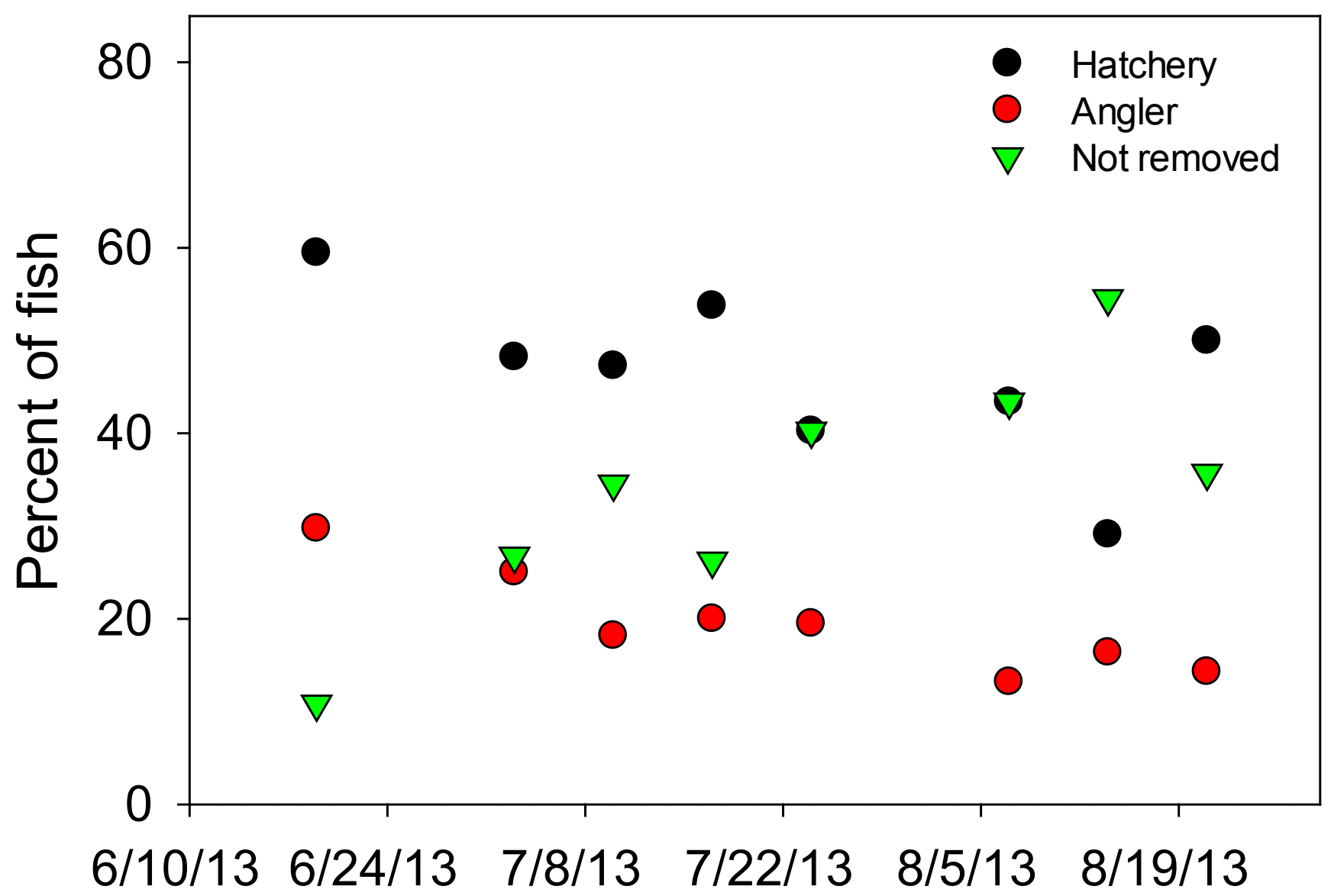

Figure 5. Graph showing percentage of weekly release groups of recycled steelhead that returned to the Cowlitz Salmon Hatchery, were captured by anglers, or were not known to have been removed from lower Cowlitz River, Washington, 2013-2014. 


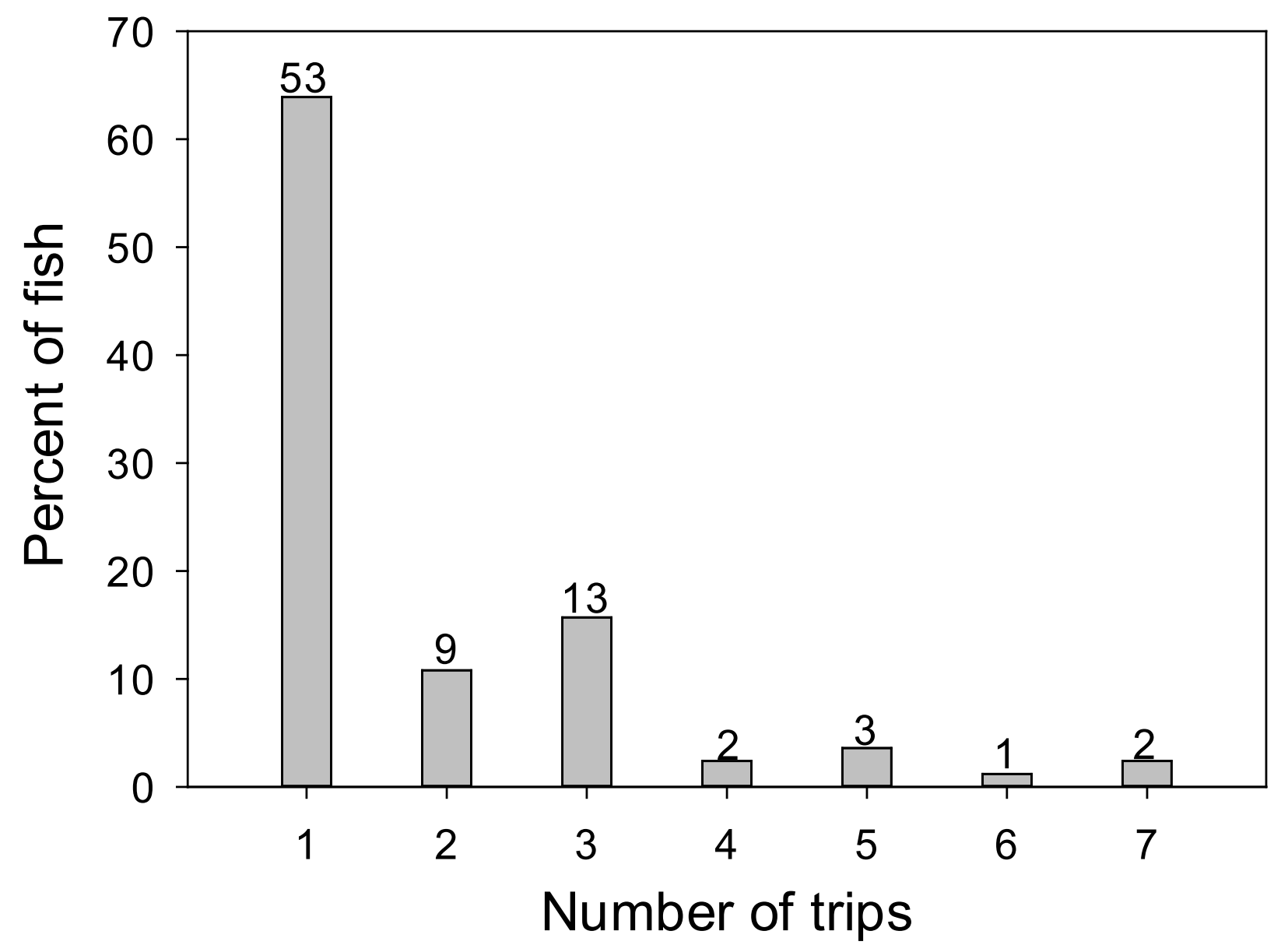

Figure 6. Graph showing percentage of radio-tagged steelhead that made trips between the Cowlitz Trout and Salmon Hatcheries during study on the lower Cowlitz River, Washington, 2013. Numbers above bars are the number of fish observed making that number of trips between sites. 


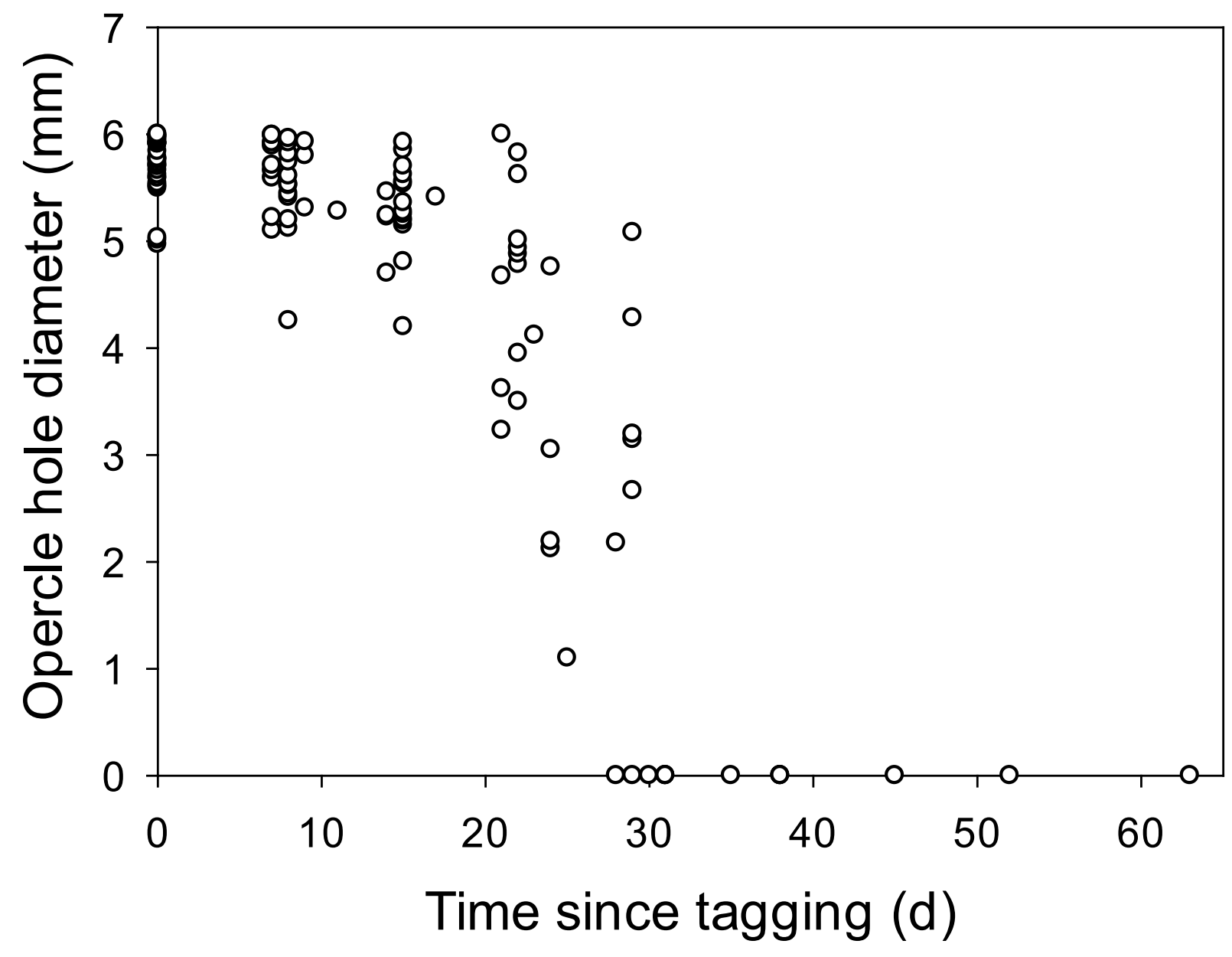

Figure 7. Graph showing relation between the inside diameter of opercle punches (in millimeters [mm]) of adult steelhead and elapsed time (in days [d]) since tagging for a study on the lower Cowlitz River, Washington, 2012. 
Table 1. Tagging dates and numbers of adult hatchery steelhead that were marked for evaluation on the Cowlitz River, Washington, June 2013-February 2014.

\begin{tabular}{rccc}
\hline Tagging date & $\begin{array}{c}\text { Number of fish that were radio- } \\
\text { tagged, Floy®-tagged, and } \\
\text { opercle punched }\end{array}$ & $\begin{array}{c}\text { Number of fish that were Floy®- } \\
\text { tagged and opercle punched }\end{array}$ & $\begin{array}{c}\text { Total number of fish } \\
\text { marked and released }\end{array}$ \\
\hline June 18, 2013 & 7 & 35 & 42 \\
June 25, 2013 & 7 & 40 & 47 \\
July 2, 2013 & 17 & 45 & 62 \\
July 9, 2013 & 14 & 55 & 69 \\
July 16, 2013 & 11 & 65 & 76 \\
July 23, 2013 & 16 & 45 & 61 \\
July 30, 2013 & 11 & 45 & 56 \\
August 6, 2013 & 14 & 45 & 59 \\
August 13, 2013 & 12 & 18 & 30 \\
Totals & 109 & 391 & 502 \\
\hline
\end{tabular}


Table 2. Summary of the fates of recycled steelhead that were released during a study on the Cowlitz River, Washington, 2013.

[All fish: All fish that were recycled during study. Radio-tagged fish: Only those fish that were radio-tagged]

\begin{tabular}{|c|c|c|}
\hline \multirow[t]{2}{*}{ Fate } & All fish & Radio-tagged fish \\
\hline & Number of fish & Number of fish \\
\hline Total number of fish released & 502 & 109 \\
\hline \multicolumn{3}{|c|}{ Recycled steelhead that did not pose a risk to wild steelhead in the lower Cowlitz River } \\
\hline $\begin{array}{l}\text { Returned to the hatchery } \\
\text { Captured by an angler } \\
\text { Left the Cowlitz River } \\
\text { Died, were harvested, or spit transmitter }\end{array}$ & $\begin{array}{l}251 \text { (50 percent) } \\
100 \text { (20 percent) }\end{array}$ & $\begin{array}{c}66 \text { (61 percent) } \\
23 \text { (21 percent) } \\
1 \text { (<1 percent) } \\
9 \text { (8 percent) }\end{array}$ \\
\hline Total $=$ & 351 (70 percent) & 99 (91 percent) \\
\hline \multicolumn{3}{|c|}{ Recycled steelhead that may have posed a risk to wild steelhead in the lower Cowlitz River } \\
\hline $\begin{array}{l}\text { Last detected in the Cowlitz River } \\
\text { Entered a Cowlitz River tributary } \\
\text { Never detected }\end{array}$ & 151 (30 percent) & $\begin{array}{l}5 \text { (5 percent) } \\
4 \text { (4 percent) } \\
1 \text { (<1 percent) }\end{array}$ \\
\hline Total $=$ & 151 (30 percent) & 10 (9 percent) \\
\hline
\end{tabular}


Publishing support provided by the U.S. Geological Survey Publishing Network, Tacoma Publishing Service Center

For additional information contact:

Director, Western Fisheries Research Center

U.S. Geological Survey

6505 NE 65th Street

Seattle, Washington 98115

http://wfrc.usgs.gov/ 
